\title{
CONSIDERATIONS ON THE TREATMENT OF QUALITATIVE CHARACTERISTICS OF ACCOUNTING INFORMATION AT THE INTERNATIONAL LEVEL AND IN VARIOUS NATIONAL ACCOUNTING SYSTEMS
}

\author{
Ionela-Cristina Breahnă-Pravăţ \\ "Vasile Alecsandri” University of Bacău \\ crisspra@yahoo.com
}

\begin{abstract}
The qualitative characteristics of accounting information presented by financial-accounting reports represent a concept which was subsequently introduced in the national legal accounting framework and, as a rule, the national conceptual frameworks represent the documents by means of which these quality criteria are established. At a worldwide level, there are more international or national organisms that have an important role in the elaboration of accounting standards in general and more specifically in the formulation of qualitative characteristics of financial reporting. We find two important ones among them, and these are: International Accounting Standards Board, which creates and promotes International Financial Reporting Standards (IFRS), and Financial Accounting Standards Board, which elaborates Generally Accepted Accounting Principles (US GAAP). However, at the level of each country a standardizing authority decides the rules for producing the financial reports and the qualitative characteristics that must be respected by the information contained in these documents. In this context, this paper aims to present a few general considerations concerning the treatment of the qualitative characteristics of the financial-accounting information in different accounting systems, such as the American one, or the British, French, German, Romanian ones, with insistence on the international approach to qualitative characteristics.
\end{abstract}

\section{Keywords}

accounting system; standardizing institution; conceptual framework; financial information; qualitative characteristics

\section{JEL Classification}

M41

\section{General aspects concerning the qualitative characteristics of information contained in financial statements}

Economic organisations produce financial-accounting information which is made available to the users. Generally, this information is formalized by accepting certain rules or regulations, a framework, a structure, but there are also cases in which this information is not formalized and respects a series of minimal requirements.

In the present paper we will focus on the type of accounting information that must strictly comply with certain rules, that is the formalized one which is most often presented by the so-called financial statements.

The preparation, transmission, interpretation and use of financial-accounting and economic information represent, in fact, the very essence of the accounting science, and this is, in the view of the American Institute of Certified Public Accountants, the process of identifying, measuring and communicating economic information, with the purpose of allowing information users to take decisions on a well-informed basis, as Rajasekaran and Lalitha (2011) affirmed. 
In order to be useful for the various types of users, this accounting information must respect a series of qualitative features.

In general terms, the concept of quality has a relatively complex meaning. When we say quality, we refer, first of all, to the quality of an object, product or service, which represents its defining feature or sum of traits that make that object or commodity be what it is and not something else. From this perspective, every object has its own quality, and the term cannot be used to signify a value relation or something similar. As a result, in order to establish if an object is indeed what it is considered to be, it must be subjected to a series of requirements or standards which must be met so that it could be useful to the beneficiary.

In financial reporting, by quality we refer to a neo-concept, a concept which is consecutive to that of accounting or financial standard and circumscribes the latter. Thus, when we approach the concept of accounting information quality we must take into account that this type of information must also respect a series of characteristics so that, just as in the case of a commodity or service, it should be useful to the representatives of accounting information demand.

\section{Qualitative characteristics in the international accounting reference framework}

The reporting entity must respect certain quality criteria regarding the accounting information generated by financial-accounting reports. At the same time, these quality norms contribute to the identification of the information types that can be useful to the representatives of accounting information demand.

From the perspective of the international organism for accounting standardization, IASB, the fundamental qualitative characteristics - that accounting information must comply with in order to be useful to existing or potential investors, money lenders or other creditors in their decision-making processes - are relevance and faithful representation. Besides these two, the financial information must also conform to the so-called enhancing qualitative characteristics, namely, comparability, verifiability, timeliness and understandability.

The application of the latter set must be maximized when possible. However, the enhancing qualitative characteristics, if taken individually or in a group, cannot offer use-value to the information if that information is irrelevant or inaccurately represented.

Additionally, according to the Conceptual Framework for General Purpose Financial Reporting, a general constraint that influences the information offered by the financial reporting is represented by the cost of obtaining such information, in the sense that the benefits generated by the reporting of information should exceed, as much as possible, the costs for its preparation and use.

The general conceptual framework for financial reporting - the basis for the international standardization of accounting information qualitative characteristics

The general conceptual framework (2010) represents, in fact, the result of the current process of actualizing the General framework of IASB and of the process of harmonizing its provisions with those of the American General framework issued by the Financial Accounting Standards Board (FASB). It refers to aspects such as the objective of financial reporting, qualitative characteristics of useful accounting information, the definition, recognition and measurement of the elements from which financial statements are constructed, as well as the concepts of capital and capital maintenance (IASB, 2011, IFRSs). 


\section{Fundamental qualitative characteristics}

As we have previously mentioned, the two essential qualitative characteristics established by IASB are relevance and faithful representation.

\section{A. Relevance}

In order to be useful, the information must be relevant for the decision-making needs of the users. Such an item of information is relevant if it can make a difference in the decision-making processes of the users, thus helping them evaluate past events, understand the present ones and anticipate the future ones, confirming or correcting their anterior measurements. The difference in the decision-making processes can occur if the financial information has a predictive and/or confirmatory value.

Prediction and confirmation represent interdependent activities and qualities. Financial information has a predictive value for its users when it allows the anticipation or prediction of the entity's future results so that it could take advantage of certain opportunities and react accordingly in adverse situations. The confirmatory value occurs when the financial information offers a feedback concerning certain past expectations, confirming, altering or disproving it.

The relevance of the information is influenced by its nature and materiality. In some cases, the nature of the information is sufficient for determining its relevance. For instance, the reporting of a new production or sale segment can affect the evaluation of the risks and opportunities the entity confronts with, no matter the importance of the results obtained by the new division in the reporting period. In other situations, both the nature and the materiality are important. It is the case of stock quantities for each of the main categories of products which are adequate for the business.

The information is significant if its omission or incorrect reporting could influence the users' economic decisions taken on the basis of the financial information regarding the reporting entity. The significance level/limit depends on the value or extent of the element or error, under the specific circumstances of omission or incorrect reporting. Thus, the significance level provides a limit or cut-off point rather than a primary qualitative characteristic needed by the financial information in order to be considered useful.

\section{B. Faithful or exact representation}

Financial information must represent exactly and faithfully the phenomena, transactions or other types of events it intends to represent. In order to achieve this objective, any financial information must be complete, neutral and free from error. The information included in financial reports must be complete, given certain limits, both considering its materiality (or physical aspect) and the costs involved (the financial aspect). More precisely, it must include all the descriptions and explanations which are necessary for the user to understand the depicted phenomenon.

The financial information must be neutral, meaning that it should lack any bias, it should not be manipulated either favourably or unfavourably, so there must be no influence exerted in their selection and presentation.

Financial information is not neutral if, through the selection or presentation of information, it can influence the making of decisions or some judgment with the purpose of obtaining a certain result instead of another one, or in the absence of relevant information, or when certain insignificant or even false aspects are highlighted, etc. Bias is, therefore, a certain form of intentional error, either by omission or other means, with the purpose of determining a certain decision on the user's part and, implicitly, a certain transaction (or the failure of making one).

Exact representation does not involve exactness in all respects. This means that the financial information that is free from error represents an item of information that describes a phenomenon without errors or omissions, so the process used to produce the information is selected and applied to the capital without any errors (IASB, 2011, IFRSs). 


\section{Enhancing qualitative characteristics}

According to the General conceptual framework, understandability, comparability, timeliness and verifiability are qualitative characteristics that enhance the usefulness of relevant and faithfully represented information. They contribute to the selection of one manner out of two alternatives that must be used in order to describe a phenomenon if we take into consideration that both are equally relevant and faithfully represented.

\section{A. Understandability}

An essential quality of the information described by financial statements is that of being easy to comprehend by its users, starting from the idea that financial reports are prepared for users who have sufficient knowledge of business and economic activities and who study or analyse the information with the proper diligence. It may sometimes happen that even well-informed and diligent users need to seek the aid of an advisor in order to understand the information regarding complex economic phenomena (IASB, 2011, IFRSs).

\section{B. Comparability}

The information supplied by a reporting entity is useful if it can be compared with similar information about other entities (comparability in space) and with similar information about the same entity for some other period (comparability in time).

A specific requirement that assists in achieving comparability is consistency. Hence, users need to be informed of the accounting policies and their modifications because an objective comparison can only be made by using the same methods.

However, the need of achieving comparability differs from uniformity and should not become an impediment or deterrent to the modernization of existing standards.

\section{Verifiability}

Verifiability helps assuring users that the information provided faithfully represents the economic phenomena it seeks to represent. Verifiability entails that different knowledgeable and independent observers could reach general agreement, although not necessarily complete consensus, that a certain description constitutes faithful representation.

In order to be verifiable, the quantified information need not be a single point estimate. A range of possible values and the corresponding possibilities can also be verified (IASB, 2011, IFRSs).

Verification can be of two types:

- direct verification - the verification of a value/amount or other representations by means of direct observation;

- indirect verification - the verification of inputs for a model, formula or other technique; the recalculation of results by using the same methodology.

\section{Timeliness}

If unjustified delays in reporting information occur, the information can lose its relevance for users. In other words, financial information needs to be available for decision-making users at the right time so that this information could influence their decisions. As a rule, the degree of timeliness is inversely proportional to the time that passes after the information is produced, but there are also items of information that continue to be timely for a longer period. 


\section{Qualitative characteristics of accounting information in other national accounting systems}

2010

The American approach to qualitative characteristics valid until

In 1978, the American accounting standardization organism, FASB, published a document entitled Statement of Financial Accounting Concepts (SFAC), a document which, in its introduction, presents the objectives, hypotheses and qualitative characteristics of financial statements.

SFAC is divided into more sections, each section containing well-defined items of information as follows:

- SFAC 1 Objectives of Financial Reporting by a Business Enterprise;

- SFAC 2 Qualitative Characteristics of Accounting Information;

- SFAC 5 Recognition and Measurement in Financial Statements;

- SFAC 6 Elements of Financial Statements;

- SFAC 7 Using Cash Flow Information and Present Value in Accounting Measurements.

SFAC 2, Qualitative Characteristics of Accounting Information, establishes a certain hierarchy of the qualitative characteristics of accounting information, based on its usefulness for decision-making purposes. This objective is achieved by respecting certain qualities such as:

- Primary characteristics:

o Relevance: capacity to make a difference in a decision;

o Reliability: information is reasonably free from error and bias;

- Secondary characteristics, mentioned in SFAC 2:

o Comparability: enables users to identify similarities and differences;

o Consistency: conformity from period to period.

The figure below summarizes the qualitative qualities by FASB approach presented in SFAC 2, qualities available until 2010, when The Single Conceptual Framework was published:

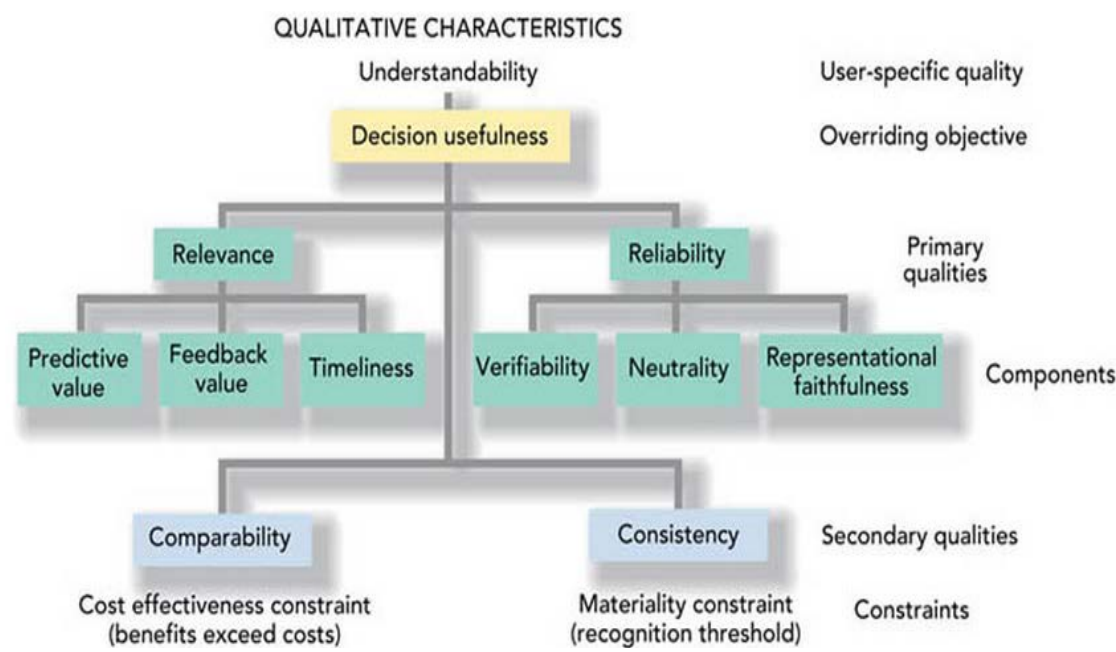

Figure 1 Qualitative characteristics according to FASB Norms valid until 2010

Source: Spiceland, D., Sepe, J., Tomassini, L., Intermediati Accounting, Student Edition, available at http://highered.mheducation.com/sites/0072994029/student_view0/ebook/chapter1/chbody1/qualitative_ch aracteristics_of_accounting_information.html) 


\section{The British approach to qualitative characteristics}

The former British organism for accounting standardization attempted to elaborate a conceptual framework in 1975. To this end, it published a document entitled Corporate Report. With reference to the British system, the framework is significantly different from the American one. Later, in 1990, the new standardizing institution, ASB, attempted to define a conceptual framework published with the title of Statement of Principles for Financial Reporting.

However, the first elements of a conceptual framework were published in 1991 and were inspired by the IASC model, the British final version being published in 1999 with the following sections or chapters:

- Objectives of financial statements;

- Entities that prepare financial statements;

- Qualitative characteristics of financial information;

- Elements of financial statements;

- Recognition criteria in financial statements;

- Measurement criteria in financial statements;

- Presentation of financial statements;

- Accounting for interests in other entities.

As far as the qualities of financial information are concerned, they are equivalent, to a great extent, to the ones presented by FASB and IASB.

Fundamental qualities are:

- relative importance;

- relevance;

- reliability.

Secondary qualities, whose absence makes information usefulness debatable, are:

- comparability - it involves the permanence of methods, disclosure of accounting policies and compliance with accounting norms;

- understandability implies reasonable knowledge of accounting on the part of the users and an adequate presentation of the information.

\section{The French approach to qualitative characteristics}

The French general framework is generally represented by regulations concerning the establishment and presentation rules of annual accounts defined by a specific document entitled General Accounting Plan.

In 1999, the French National Accounting Council elaborated a new version of the General Accounting Plan which was presented in the form of a code. The code is divided into articles, a situation which is similar to a legal framework, and contains five chapters:

- Title I - Object and Principles of Accounting - refers to the application by any natural person or legal entity of accounting norms if they are subject to the legal obligation of drawing up annual accounts. In this chapter there is no reference to the necessity of producing information for users.

- Title II - Definition of assets, liabilities, income and charges - has a conceptual character but, as in the case of the first title, it does not make any reference to information provided by financial statements or to information users.

- Title III - Accounting Recognition and Valuation Rules - this part discuses the date, valuation and accounting recognition manner for assets and liabilities, as well as for charges and income.

- Title IV - Keeping, Structure and Functioning of Accounts - this title represents one of the most original elements of the French standardizing system and discusses the accounts plan. 
- Title V - Synthesis documents - presents models of proposed annual accounts, namely, the standard, abridged and expanded ones.

The French conceptual framework is in a process of expanding and tends to get very close to the American one. If the standardization and regulation of individual accounts still continues to be constrained by the notion of patrimony, the standardization and regulation of group/collective accounts, under the influence of the VII ${ }^{\text {th }}$ European Directive, subsequently updated by Directive no. 34/2013, offers those who prepare financial statements various possibilities to go beyond the traditional patrimonial framework (Colasse, 2007).

When analysing the quality of financial statements, the following hierarchy emerges: faithfulness, regularity/uniformity, honesty - with the meaning of respecting the rule of caution. The following table presents a comparative analysis of the qualitative characteristics of accounting information, namely, explicit and implicit characteristics, which are found in the French accounting legal regulations.

Table 1 Qualitative characteristics of accounting information according to the French General Accounting Plan

\begin{tabular}{|l|l|l|}
\hline $\begin{array}{l}\text { Qualitative } \\
\text { characteristics }\end{array}$ & $\begin{array}{l}\text { GAP } \\
\text { Individual accounts }\end{array}$ & $\begin{array}{l}\text { GAP } \\
\text { Consolidated accounts }\end{array}$ \\
\hline Regularity & $*$ & \\
\hline Verifiability & Implicit (regularity) & Implicit (regularity \\
\hline Accounting options & $\begin{array}{l}\text { Unknown (contrary to } \\
\text { regularity) }\end{array}$ & $*$ \\
\hline Comparability & $*$ & $*$ \\
\hline Exhaustiveness & $*$ & $*$ \\
\hline Relative importance & $*$ & $*$ \\
\hline Permanence of methods & $*$ & $*$ \\
\hline $\begin{array}{l}\text { Relevance (influences the users' } \\
\text { decisions) }\end{array}$ & $*$ & $*$ \\
\hline Prudence/caution & $*$ & $*$ \\
\hline Faithful representation & $*$ Undefined & $*$ Undefined \\
\hline Neutrality & Connected to fiscal policies & $*$ \\
\hline Balance advantages/costs & Unknown & Implicit \\
\hline Respecting terms & Unknown & Unknown \\
\hline Comprehension/understandability & Inexplicit & Inexplicit \\
\hline Priority of funds over form & Unrecognized & $*$ \\
\hline Reliability & Regularity + honesty & Regularity + honesty \\
\hline (Source: Quoted from Walton, P., Haller, A., Raffournier, B. (2003), International accounting, \\
\hline
\end{tabular}

\section{The Romanian approach to qualitative characteristics}

According to the Romanian regulations, the four qualitative characteristics of the information contained in financial statements are: understandability, relevance, credibility/reliability and comparability.

The qualitative characteristics that must be respected by the financial-accounting information, in compliance with the accounting norms that are applied in Romania, are presented in the figure below: 


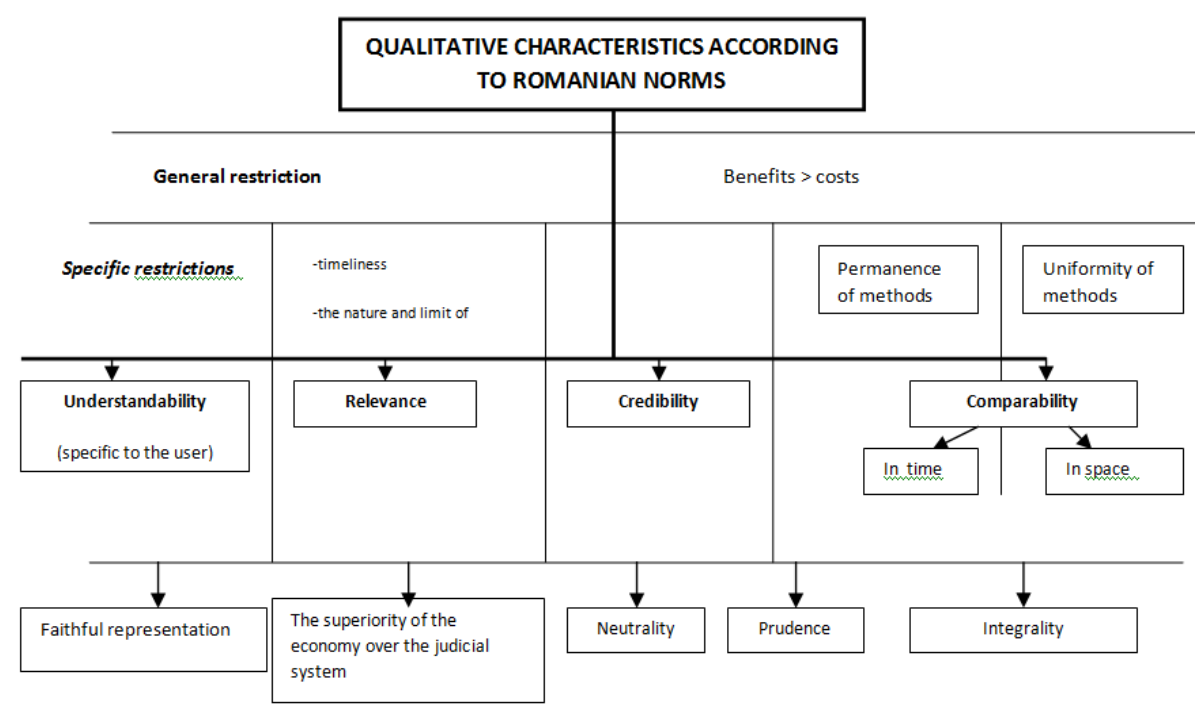

Figure 2 Qualitative characteristics according to Romanian Norms

Source: Toma, C. (2011), Contabilitatea financiară, Tipo Moldova, Iasi, p. 126.

\section{Conclusions}

As we have shown in this article, at a global level we can identify the tendency of harmonization and even convergence of the qualitative characteristics of the information contained in accounting-financial reports. However, differences still exist in the expression, structuring, presentation and standardization of qualitative criteria regarding accounting-financial information.

The table below briefly presents the structure of the qualitative characteristics established by the accounting systems analyzed in our study:

Table 2 Qualitative characteristics of accounting information in various countries

\begin{tabular}{|c|c|c|}
\hline Accounting & Main standardizing organism & Qualitative characteristics \\
\hline Romania & - $\quad$ MFP -The Ministry of Public Finances & $\begin{array}{l}\text { - Understandability; } \\
\text { - Relevance; } \\
\text { - Credibility } \\
\text { - Comparability. }\end{array}$ \\
\hline France & $\begin{array}{l}\text { - } \text { ANC - Accounting Standards Authority: } \\
\text { - unique standardizing organism in accounting }\end{array}$ & $\begin{array}{l}\text { - Faithfulness; } \\
\text { - Regularity; } \\
\text { - Honesty. }\end{array}$ \\
\hline $\begin{array}{c}\text { Great } \\
\text { Britain }\end{array}$ & $\begin{array}{l}\text { FRC - Financial Reporting Council: } \\
\text { - a “collective creation” of the accounting professionals, } \\
\text { the financial community and the government; } \\
\text { - it manages five councils, including the ASB } \\
\text { (Accounting Standards Board) }\end{array}$ & $\begin{array}{l}\text { - Main qualities: } \\
\text { - relative importance; } \\
\text { - pertinence/relevance and } \\
\text { reliability. } \\
\text { - } \quad \text { Secondary qualities: } \\
\text { - comparability; } \\
\text { - understandability. }\end{array}$ \\
\hline USA & $\begin{array}{l}\text { - FASB -Financial Accounting Standards Board: } \\
\text { - a private organism that is responsible with } \\
\text { establishing the generally approved accounting } \\
\text { principles for the USA }\end{array}$ & $\begin{array}{l}\text { - } \quad \text { Primary qualities: } \\
\text { - relevance; } \\
\text { - reliability; } \\
\text { - } \quad \text { Secondary qualities: } \\
\text { - comparability; } \\
\text { - consistency. }\end{array}$ \\
\hline
\end{tabular}




\section{References}

Colasse, B., avec la collab. Le Lesage, C. (2007), Introduction á la comptabilité, 10e édition, Paris, Economica.

Breahnă-Pravăţ, I. C. (2013), Basic Aspects Concerning The Single Conceptual Framework, în Revista Studies and Scientific Researches - Economics Edition, 18, 128-136.

Feleagă, N. (1999), Sisteme contabile comparate, vol. 1, Bucharest, Editura Economică.

IASB (2011), International Reporting Financial Standards (IFRSs). Official rules issued from 1 January 2012. Includes IRFSs which shall enter into force after 1 January 2011 but does not include the IFRSs they replace, Part A Conceptual framework and provisions, Bucharest, CECCAR Publishing House.

IASB (2013), DP/2013/1 - A Review of the Conceptual Framework for

Ministerul Finanţelor Publice, Ordinul nr. 3055/2009, pentru aprobarea Reglementărilor contabile conforme $\mathrm{cu}$ directivele europene, publicat în Monitorul Oficial al României, Partea I, nr. 766 din 10.11.2009.

Obert, R. (2011), Le nouveau cadre conceptuel de l, IASB, Revue Française de Comptabilité, 439.

Rajasekaran, V., Lalitha, R. (2011), Financial Accounting, New Delhi, published by Dorling Kindesley licensees of Pearson Educational in South Asia, available at http://books.google.ro/books?id=qP3XNPoLO7wC\&printsec=frontcover\&dq= Rajasekaran,+V.,+Lalitha,+R.+-

+Financial+Accounting\&hl=ro\&sa=X\&ei=vmy2U92DK6qv7AanxYGwCA\& ved=0CCcQ6AEwAA\#v=onepage\&q=Rajasekaran\%2C\%20V.\%2C\%20Lalith a\%2C\%20R.\%20-\%20Financial\%20Accounting\&f=false.

Ristea, M., Dumitru, C., Ioanăş, C., Irimescu, A. (2009), Contabilitatea societăților comerciale, vol. I, Bucharest, Editura Universitară.

Rotilă, A. (2011), Reglementări și practici contabile specifice, Bacău, Editura Alma Mater.

Spiceland, D., Sepe, J., Tomassini, L., Intermediati Accounting, Student Edition, available at http://highered.mheducation.com/sites/0072994029/student_ view0/ebook/chapter1/chbody1/qualitative_characteristics_of_accounting_info rmation.html.

Tabără, N., Horomnea, E., Mircea, M. C. (2010), Contabilitatea internaţională, Ediţia a II-a, Iaşi, Editura Tipo Moldova.

Toma, C. (2011), Contabilitatea financiară, Iaşi, Editura Tipo Moldova. 